\title{
An Investigation of the Effects of Ageing Parameters on Wear Behaviours and Electrical Conductivity of $\mathrm{Cu}-\mathrm{Co}-\mathrm{Be}$ Alloys
}

\begin{abstract}
D. ÖZYÜREK, M. YILDIRIM AND T. TUNÇAY*
Karabük University, Technology Faculty, Department of Manufacturing Engineering, Karabük, Turkey

In this study, the effects of ageing parameters were investigated on wear behaviours and electrical conductivity of $\mathrm{Cu}-\mathrm{Co}-\mathrm{Be}$ alloy. The samples were quenched at room temperature after solution heat treated for $1 \mathrm{~h}$. Then, ageing processes were applied for three different temperatures $\left(470{ }^{\circ} \mathrm{C}, 500^{\circ} \mathrm{C}, 530^{\circ} \mathrm{C}\right)$ and for three different ageing times $(1,2,3 \mathrm{~h})$. Microstructure examining, electrical conductivity and hardness measurements were carried out after ageing process. On the samples, which obtained the highest hardness values from hardness test $\left(470{ }^{\circ} \mathrm{C}\right)$, there were carried out wear tests with $1 \mathrm{~m} \mathrm{~s}^{-1}$ sliding speed under $30 \mathrm{~N}$ at four sliding distance (500-2000 m). Results clearly show that the highest hardness values were measured for samples aged at $470{ }^{\circ} \mathrm{C}$ for $3 \mathrm{~h}$ and hardness values were decreased with increasing ageing temperature. The lowest weight loss values were evaluated for samples aged at $470{ }^{\circ} \mathrm{C}$ for $3 \mathrm{~h}$. The highest electrical conductivity values were measured at $500{ }^{\circ} \mathrm{C}$ for $1 \mathrm{~h}$ aged samples.
\end{abstract}

DOI: 10.12693/APhysPolA.129.559

PACS/topics: 81.40.Pq

\section{Introduction}

$\mathrm{Cu}$-alloys are widely used in many sectors, particularly in the automotive industry. These alloys are preferred especially in trolley wire, in spot resistance welding electrodes and production of certain components used in nuclear power plants. Also, it is increasingly used in specific fields which require high electrical conductivity and wear resistance $[1,2]$. Dry sliding wear behaviours of $\mathrm{Cu}$-alloys are very similar to the wear behaviours of ductile metals and their alloys. Electrical and thermal conductivity characteristics of these alloys can be improved like their mechanical properties. Aging heat treatment is one of the preferred methods to improve the mechanical properties of these alloys without reducing their electrical and thermal conductivities. Dimensions and distribution of the second phase precipitates formed in the structure with ageing are important factors in increasing the strength and hardness. The Guinier-Preston (GP) zones formed in the structure at the first stage of ageing transformed to $\gamma^{\prime}$ metastable phase and $\gamma$ stable phase with the increasing ageing time [3-5]. Previous studies report that the wear behaviour of the alloy can be improved depending on the ageing conditions [6, 7]. In addition, different wear mechanisms such as oxidation, abrasive and adhesive wear mechanisms take place in $\mathrm{Cu}$ alloys depending on the load and sliding speed used in wear tests. In this study, ageing heat treatment was applied to $\mathrm{Cu}-\mathrm{Co}-\mathrm{Be}$ alloy containing $2 \%$ Co and $0.5 \%$ Be at three different temperatures and for three different times, and the effects of ageing parameters on electrical conductivity and dry sliding wear behaviour of the alloy were investigated.

*corresponding author; e-mail: tanseltuncay@karabuk.edu.tr

\section{Materials and method}

The $\mathrm{Cu}-\mathrm{Co}-\mathrm{Be}$ containing $2 \% \mathrm{Co}$ and $0.5 \%$ Be used in this study was obtained from De Le Bronze company. For ageing heat treatment, the samples were taken into the solution for $1 \mathrm{~h}$ at $920^{\circ} \mathrm{C}$. Quenched samples were aged at three different temperatures $\left(470,500\right.$, and $\left.530^{\circ} \mathrm{C}\right)$ for three different times $(1,2$, and $3 \mathrm{~h}$ ). Electrical conductivity was measured with Solatron 1296 Electric interface and SI 1287 Electrochemical interface. For microstructure analysis, the samples were etched with $50 \mathrm{ml}$ ethanol, $1 \mathrm{ml} \mathrm{HF}, 8 \mathrm{ml} \mathrm{HNO}_{3}$ and $4 \mathrm{ml} \mathrm{HCl}$ solution for $60 \mathrm{~s}$ following standard metallographic preparation. Prepared samples were examined using scanning electron microscope (SEM) Zeiss-Ultra/Plus (FEG) and energy dispersive spectroscopy (EDS). Hardness measurements were conducted with $\left(\mathrm{HMV}_{0.5}\right)$ Shimadzu microhardness measurement device. Wear tests were performed with a pin-on-disc type wear testing device according to the ASTM-G99-05. In wear tests, $30 \mathrm{~N}$ load and $1 \mathrm{~m} \mathrm{~s}^{-1}$ sliding speed were applied for four different sliding distances (500-2000 m). Prior to wear tests, samples surfaces were prepared with 1200 grade $\mathrm{SiC}$ sand paper in order to ensure full contact between steel disc and sample surfaces. All wear tests were conducted at room temperature and under dry sliding conditions. The wear surfaces were examined with SEM after the wear tests.

\section{Results and discussion \\ 3.1. Microstructural characterization}

Microstructure SEM images and EDS results of the starting material and the $\mathrm{Cu}-\mathrm{Co}-\mathrm{Be}$ alloy aged at $500^{\circ} \mathrm{C}$ for $2 \mathrm{~h}$ are shown in Fig. 1 and Table I.

In age-hardenable Cu-alloys, supersaturated solid solution occurs after high temperature solid solution treatment and quenching. Dissolved atoms in solid solution tend to form precipitates during the ageing treatment. It can clearly be seen on the microstructure SEM image of 


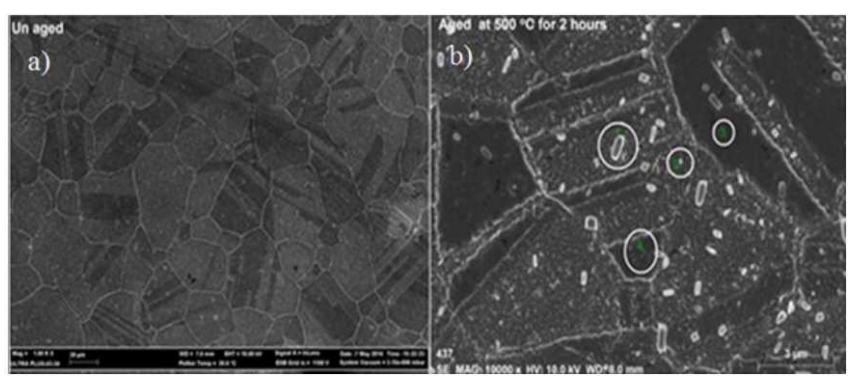

Fig. 1. Micro structure SEM images of the starting material (a) and the $\mathrm{Cu}-\mathrm{Co}-\mathrm{Be}$ alloy aged at $500^{\circ} \mathrm{C}$ for $2 \mathrm{~h}(\mathrm{~b})$.

TABLE I

The $\mathrm{Cu}-\mathrm{Co}-\mathrm{Be}$ alloy aged at $500{ }^{\circ} \mathrm{C}$ for $2 \mathrm{~h}$ (Fig $1 \mathrm{~b})$ - EDS results.

\begin{tabular}{c|c|c|c}
\hline \hline \multirow{2}{*}{ Location } & \multicolumn{3}{|c}{ Elements [wt.\%] } \\
\cline { 2 - 4 } & Be & Co & Cu \\
\hline 1 & 1.39 & 29.22 & 69.39 \\
2 & 1.10 & 0.83 & 98.06 \\
3 & 0.89 & 1.20 & 97.91 \\
4 & 0.99 & 1.31 & 97.70
\end{tabular}

aged alloy that second phase precipitates formed during the ageing treatment (Fig. 1b). It is understood from the EDS analysis results given in Table I that these precipitates are Co- and Be-rich. According to Yağmur et al. [5], metastable $\gamma^{\prime}$ precipitates grow and transform to stable $\gamma$ precipitates as the duration of the ageing treatment increases. It is also observed that second phase precipitates are distributed homogeneously in the structure of alloy.

\subsection{Hardness and electrical conductivity}

Hardness and electrical conductivity values (\% IACS) of $\mathrm{Cu}-\mathrm{Co}-\mathrm{Be}$ alloy before and after the ageing heat treatment at different temperatures and durations are given in Table II.

TABLE II

Hardness and \% electrical conductivity values of the samples aged at different temperatures for different durations.

\begin{tabular}{c|c|c|c}
\hline $\begin{array}{c}\text { Ageing } \\
\text { temperature } \\
{ }^{\circ} \mathrm{C}\end{array}$ & $\begin{array}{c}\text { Aging } \\
\text { time } \\
{[\mathrm{h}]}\end{array}$ & $\begin{array}{c}\text { Electrical } \\
\text { conductivity } \\
\text { [\% IACS] }\end{array}$ & $\begin{array}{c}\text { Hardness } \\
{[\text { HMV] }}\end{array}$ \\
\hline & Un-aged & 77.95596 & 106 \\
\hline 470 & 1 & 84.63403 & 234.6 \\
& 2 & 86.39965 & 250 \\
500 & 3 & 86.14106 & 259.2 \\
& 1 & 90.02204 & 227.4 \\
& 2 & 75.22076 & 220.6 \\
530 & 3 & 83.91571 & 210 \\
& 1 & 80.26296 & 218 \\
& 2 & 76.89184 & 218.8 \\
& 3 & 88.43324 & 203
\end{tabular}

Table II shows that the highest hardness value was measured for the samples aged at $470{ }^{\circ} \mathrm{C}$ for $3 \mathrm{~h}$, and the hardness decreases by the increasing ageing time and temperature $\left(500^{\circ} \mathrm{C}\right.$ and $\left.530^{\circ} \mathrm{C}\right)$. The effects on hardness and strength of second phase precipitates formed in the structure by ageing are usually determined by the relationship between precipitates and dislocations. This relationship is explained with a mechanism known as the Orowan mechanism

$$
\tau_{\rho}=\frac{0.81 G b}{2 \pi(1-v)^{1 / 2}} \frac{\ln (2 r / b)}{\lambda-2 r},
$$

where $G$ is the sliding module of the copper matrix, $b$ is the burger vector, $r$ is the mean radius of the precipitates and $\lambda$ is the dislocation cutting distance [3]. Table II shows the electrical conductivity variations (IACS \%) of the $\mathrm{Cu}-\mathrm{Co}-\mathrm{Be}$ alloy depending on ageing treatment temperature and time. The highest conductivity values were obtained for the samples aged at $500^{\circ} \mathrm{C}$ for $3 \mathrm{~h}$. When the IACS \% value obtained is correlated with the electrical conductivity value of the sample with the highest hardness value (aged at $470^{\circ} \mathrm{C}$ for $3 \mathrm{~h}$ ), it is understood that the conductivity is similar. Comparing the hardness and electrical conductivity values of the samples with the highest hardness and electrical conductivity values with un-aged samples, it can easily be concluded that the ageing process is a must for these alloys. It is understood that the Co- and Be-rich precipitates were effective on the increasing IACS \% value. Over-ageing decreases the hardness and increases the electrical conductivity of alloy. Aging treatment causes distortion at the lattice of the alloy. Although the lattice distortion of the alloy usually aggravates electrical conductivity, it is understood that the electrical conductivity increased with the increasing $\mathrm{Co}$ and Be content in the second phase precipitates. The electrical conductivity increases as a result of these two mechanisms that take place at the same time and compensate each other. The electrical conductivity results obtained are supported by an earlier study [8].

\subsection{Wear tests}

Since the samples aged at $470^{\circ} \mathrm{C}$ had the highest hardness values, the wear tests were performed on these $\mathrm{Cu}-$ $\mathrm{Co}-\mathrm{Be}$ alloys aged at $470^{\circ} \mathrm{C}$ for three different times. The weight loss of the $\mathrm{Cu}-\mathrm{Co}-\mathrm{Be}$ alloy aged at $470^{\circ} \mathrm{C}$ for three different times are given in Fig. 2.

As can be seen in Fig. 2, the samples that were aged at $470{ }^{\circ} \mathrm{C}$ for $1 \mathrm{~h}$ had the highest weight loss value after the wear tests under $30 \mathrm{~N}$ load with $2000 \mathrm{~m}$ sliding distance and the samples aged at the same temperature for $3 \mathrm{~h}$ had the lowest value. The obtained results clearly support the hardness results given in Table II. It is understood that the samples with a high hardness value had a low weight loss and the samples with a low hardness value had a high weight loss. These results are also in agreement with some previous studies [6,9]. According to these results, the weight loss decreases by the increasing treatment time. This is because the size of the second phase precipitates formed in the structure increases by 


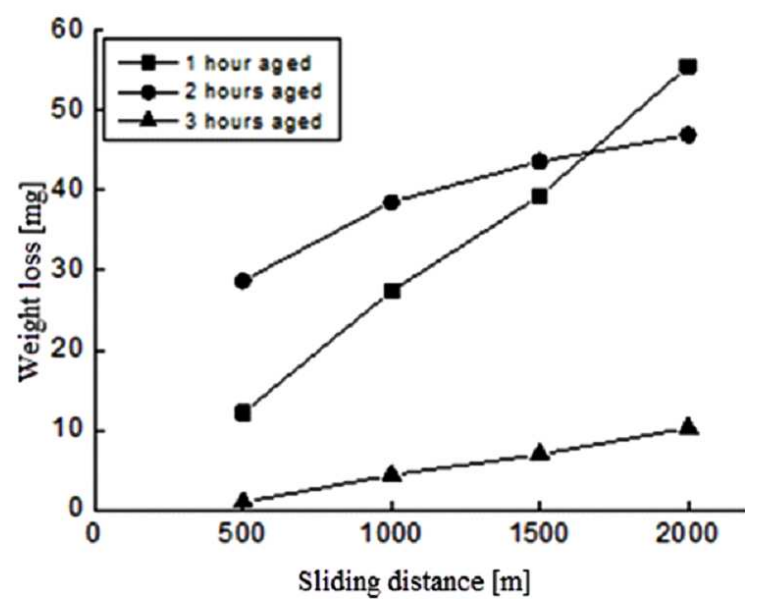

Fig. 2. The weight loss of the $\mathrm{Cu}-\mathrm{Co}-\mathrm{Be}$ alloy aged at $470{ }^{\circ} \mathrm{C}$ for three different times.

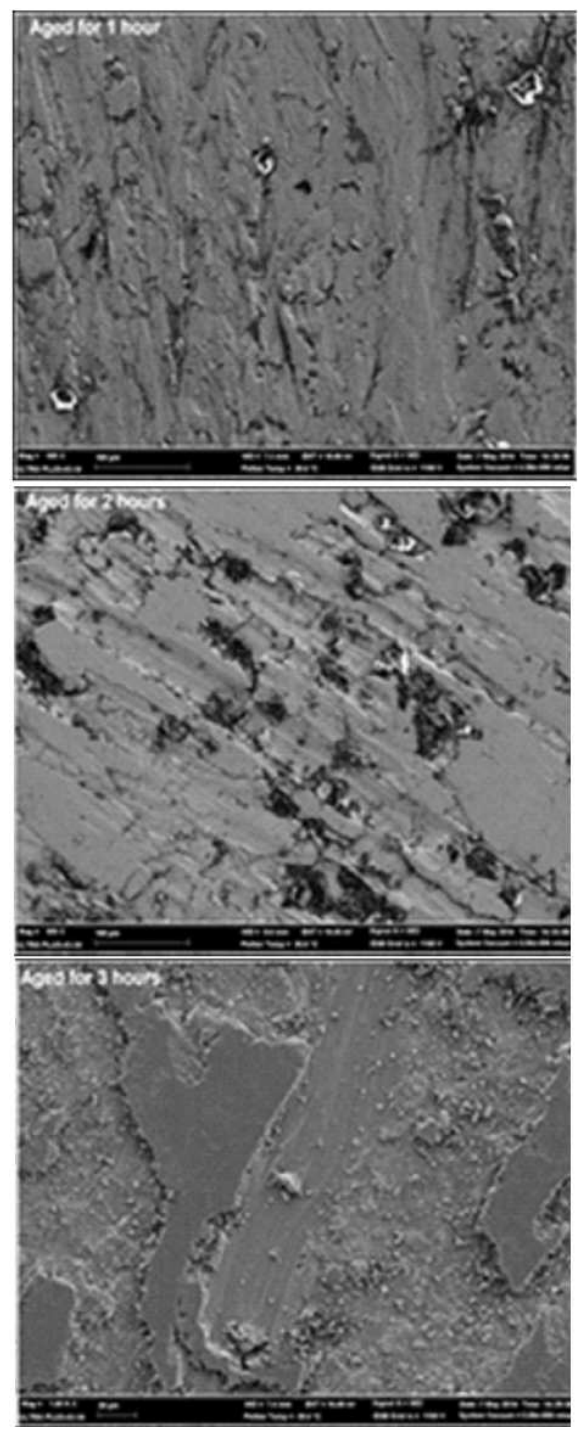

Fig. 3. Worn surface SEM images of the $\mathrm{Cu}-\mathrm{Co}-\mathrm{Be}$ alloy aged at $470{ }^{\circ} \mathrm{C}$ for three different times. the treatment time which makes dislocation movement more difficult in the wear tests. SEM images of the worn surfaces after the wear tests are given in Fig. 3 .

Figure 3 shows the SEM images of heavy plastic deformation on the worn surfaces of all samples which was a function of the ageing time and sliding system. It can also be seen that particles, detached from the surface during the wear tests due to tribosystem, smear to the sample surface with adhesion effect. It was also observed that local debris occurred on the sample surfaces during the wear tests.

\section{Conclusion}

In this study, the effects of ageing treatment parameters on electrical conductivity and wear behaviour of $\mathrm{Cu}-\mathrm{Co}-\mathrm{Be}$ alloys were investigated. Following conclusions can be made from the study:

- Stable $\gamma$ precipitates were successfully produced using ageing treatment in the structures of $\mathrm{Cu}-\mathrm{Co}-\mathrm{Be}$ alloys that were aged at three different temperatures for three different times.

- According to hardness measurement results, the samples that were aged at $470{ }^{\circ} \mathrm{C}$ for $3 \mathrm{~h}$ have the highest hardness value.

- According to electrical conductivity measurement results, the samples that were aged at $500^{\circ} \mathrm{C}$ for $1 \mathrm{~h}$ has the highest electrical conductivity value.

- While the samples that were aged at $470^{\circ} \mathrm{C}$ for $3 \mathrm{~h}$ had the lowest weight loss after the wear tests, the samples that were aged at the same temperature for $1 \mathrm{~h}$ had the highest weight loss.

\section{References}

[1] H. Fuxiang, L. Chao, M. Jusheng, N. Honglong, G. Zhiting, L. Chao, G. Shumei, Y. Xuetao, W. Tao, L. Hong, L. Huafen, Scr. Mater. 48, 97 (2003).

[2] Q. Liu, X. Zhang, Zhang, Y. Ge, J. Wang, J.Z. Cui, Metall. Trans. A 37A, 3233 (2006).

[3] X. Guoliang, W. Qiangsong, M. Xujun, X. Baiqing, P. Lijun, Mater. Sci. Eng. 558, 326 (2012).

[4] P. Scardi, M. Leoni, G. Straffelini, G. De Giudici, Acta Mater. 55, 2531 (2007).

[5] L. Yağmur, O. Duygulu, B. Aydemir, Mater. Sci. Eng. A 528, 4147 (2011).

[6] H.B. Yıldız, M. Yaşar, Metallofiz. Noveishie Tekhnol. 29, 1659 (2007).

[7] D. Özyürek, İ. Çiftci, T. Tuncay, Mater. Test. 55, 468 (2013).

[8] İ. Sağlam, D. Özyürek, K. Çetinkaya, Bull. Mater. Sci. 34, 1465 (2011).

[9] Y. Altunpak, Sci. Res. Essays 5, 2997 (2010). 